\title{
Smart Universities Walk the Talk of Commitment.
}

\author{
EVERARD VAN KEMENADE \\ Van Kemenade Audit Coaching and Training
}

\begin{abstract}
Twenty first century cities encounter lots of problems regarding transportation, governance, information technology, environment, resources. Smart cities are needed and already booming all over the world. The concept of Smart Cities needs to be defined. The Smart City model by Giffinger et al (2007) is useful in this respect. It discerns six topics: smart living, smart governance, smart economy, smart mobility, smart environment and smart people. This article focuses on the consequences of smart cities for universities. They can teach their students specific competences in e.g. Information Technology, Urbanisation, Smart Cities and Sustainability. They can do research in such areas. But: "The centrality of 'smart citizens', rather than 'smart cities', can be easily overlooked." (Slovava and Okwechime, 2016). Smart Cities can only function, if their citizen become smart. For universities that means teaching general competences to all students like problem solving, creativity, flexibility and critical thinking. Crucial is knowledge and skills regarding sustainability. For that matter the university will need to be an example to be credible.

Actually universities need a paradigm shift: from control and continuous improvement to commitment, a preliminary stage to real breakthrough. The stage the university is in can be measured with the Emergency Model (c) (Van Kemenade, 2017). The instrument can also point out what still needs to be done to achieve the breakthrough that is needed for universities in times of Smart Cities.
\end{abstract}

Keywords: Smart City, Smart University, breakthrough, quality paradigms, commitment paradigm

\section{Introduction}

"Quand tu veux construire un bateau, ne commence pas par rassembler du bois, couper des planches et distribuer du travail, mais réveille au sein des hommes le désir de la mer grande et large"1. Antoine de St-Exupery.

Twenty first century cities encounter huge problems all over the world. Traffic is often getting out of control, making cities experience continuous traffic jams and enormous loss of time and money. With the urbanisation some cities in countries in transition are booming and have difficulty to take care of supply of water, food and fuel. The environmental consequences of rapid growth are beyond control. You can also put it in a more positive way:

"Globilization with trade liberalization measures and fast technological changes altering the relations of production, distribution and consumption, has very substantial effects on city developments. As one important consequence, (network-) economies evolved"[.... with easier physical movement, globalized players making decisions with no regard to national boundaries" (Thornley, 2000). Cities face the challenge of combining competitiveness and sustainability simultaneously. A solution might be to build and rebuild cities to become smarter: Smart City.

\footnotetext{
1 "If you want to build a ship, don't drum up people to collect wood and don't assign them tasks and work, but rather teach them to long for the endless immensity of the sea".

International conference on Quality in Education and Training 2017, Innovative Universities for Smart Cities, Kenitra, 12-13 May
} 


\section{What is a Smart City?}

When you google smart city definition, you get many commercial project developers and little knowledge on what it actually is. Wikipedia defines a smart city as "an urban development vision to integrate multiple information and communication technology (ICT) and Internet of things (IoT) solutions in a secure fashion to manage a city's assets - the city's assets include, but are not limited to, local departments' information systems, schools, libraries, transportation systems, hospitals, power plants, water supply networks, waste management, law enforcement, and other community services". The concept of smart cities covers all sorts of activities depending on the definition of the word smart: digital city, sustainable city, knowledge city. No definition is set until now, as far as I know.

Deakin and Al Wear (2011) list four factors that contribute to define a smart city:

1. The application of a wide range of electronic and digital technologies to communities and cities

2. The use of ICT to transform life and working environments within the region

3. The embedding of such ICTs in government systems

4. The territorialisation of practices that brings ICTs and people together to enhance the innovation and knowledge that they offer.

Because of the role given to citizens I prefer the definition by Giffinger et al. (2007): "A smart city is a city well-performing in a forward-looking way in the six characteristics, smart people, smart economy, smart governance, smart mobility, smart environment and smart living, built on the smart combination of endowments and activities of self-decisive, independent and aware citizens".

\section{Smart Economy}

Smart People

\section{Smart Governance}

\section{Smart Mobility}

\section{Smart Environment}

\section{Smart Living}

Figure 1: the six characteristics of a smart city (Giffinger et al., 2007)

All six characteristics are further defined in factors and indicators. We give here the example of the Smart People. 


\begin{tabular}{|l|l|}
$\begin{array}{l}\text { SMART PEOPLE } \\
\text { factor }\end{array}$ & $\begin{array}{l}\text { SMART PEOPLE } \\
\text { indicator }\end{array}$ \\
\hline Level of qualification & $\begin{array}{l}\text { Importance as knowledge centre (top } \\
\text { research centres, top universities etc.) }\end{array}$ \\
\hline $\begin{array}{l}\text { Population qualified at levels 5-6 ISCED } \\
\text { Affinity to life }\end{array}$ & Foreign language skills \\
\hline Boarning & Book loans per resident \\
\hline Social and ethnic plurality & Participation in language courses \\
\hline Flexibility & Participation in life-long-learning in \% \\
\hline Share of foreigners \\
\hline Share of nationals born abroad \\
\hline
\end{tabular}

\begin{tabular}{|l|}
\hline Creativity \\
Cosmopolitanism/Open- \\
mindedness
\end{tabular}

Share of people working in creative industries

Voters turnout at European elections

Immigration-friendly environment (attitude towards immigration)

Knowledge about the EU

Participation in Public Life

Voters turnout at city elections

Participation in voluntary work

Figure 2: Operationalisation of Smart people (Giffinger et al, 2007)

According to the European Project of the Vienna University of Technology Luxemburg is the (medium-size) city in Europe that meets the Smart City standards best.

International conference on Quality in Education and Training 2017, Innovative Universities for Smart Cities, Kenitra, 12-13 May 


\section{Smart Universities}

What does this development towards Smart Cities require from the universities in or near the city? Smart cities need people with competences in the fields that are involved. So universities are supposed to teach and research on technology, smart cities a such, urbanisation, sustainability. In fact on all the six topics of the characteristics mentioned in figure 1.

And if we talk about sustainability specifically teaching and researching is not enough. The university itself should live the sustainability in its behaviour as well to be credible for the education it offers. How can we teach students to be careful with scarce resources, if the university itself spoils e.g water in an enormous way?

However, that is not enough. As Slovava and Okwechime (2016) state: "The centrality of 'smart citizens', rather than 'smart cities', can be easily overlooked." A high-tech city may not be that smart if citizens don't behave smartly: universities and education in general need to provide general smart competences of all people!!!! Then we talk about competences for the next decade like problem solving, critical thinking and creativity, for all students, especially for all future leaders.

\section{Top 10 skills}
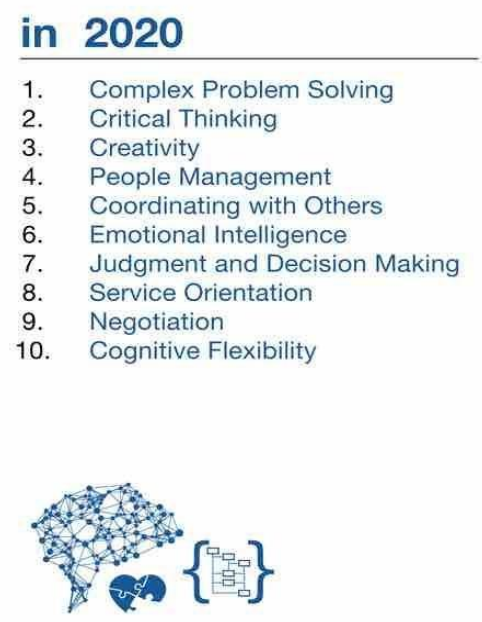

Source: Future of Jobs Report, World Economic Forum

\section{in 2015}
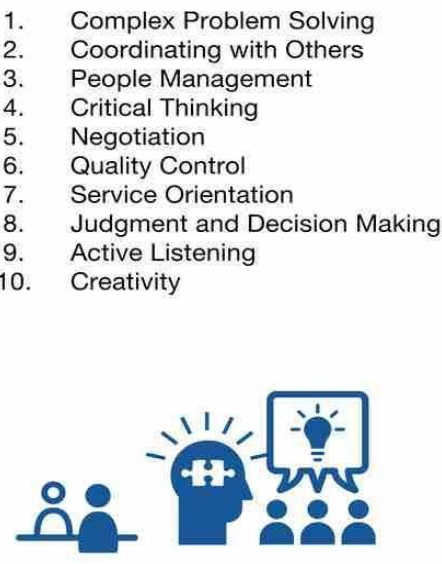

Figure 3: top ten skills for leadership

These topics require a different way of teaching, that can be described as student centred. These changes actually may be a a paradigm shift for many universities at this moment: we need universities to involve in a new value system. 


\section{Value systems}

Beck and Cowan (1996) discern eight value systems, but for the sake of transparency of our argumentation, we only present four. These four value systems provide us with four new quality paradigms to define quality. The paradigms of: process control; continuous improvement; commitment and breakthrough.

In fact we can speak of four different paradigms. Kuhn defined a paradigm as: "universally recognised scientific achievements that for a time provide model problems and solutions to a community of practitioners" (Kuhn, 1970). Based on these four value systems, four different views on quality and on quality management can be stated:

1. Control (Order)

2. Continuous improvement (Success)

3. Commitment (Community)

4. Breakthrough (Synergy)

We hereby build on the ideas of Jouslin de Noray (2004), Hardjono (2005) and Shiba (2005; 2006).

\section{Control}

In the first value system derived from Beck and Cowan the world is a potential chaos, needs to get into order. So people stick to rules and procedures. They are loyal or comply. Stability and one-track-minds are dominant. They gave the value system the colour blue and call it "order" or "TruthForce". In terms of quality management we prefer the title of control. Jouslin de Noray calls process control the first revolution in quality management. This is about rules, procedures, standards. Standards have been in use from the time of the Egyptians building their pyramids and the guilds in the Middle Ages controlling the quality of the output of the craftsmanship. We recognize this paradigm in the scientific management of Taylor (1856-1915) and in Shewhart's publication Economic Control of Quality of manufacturing Product. But also the ISO standards originally were meant to control the quality of the products of suppliers and fit in this paradigm. Object can be a product, a process, a system or a person (personal certification).

Shiba (2005) gives a symbol to this paradigm.. "Process control is symbolically indicated by a flat line indicative of the goal of synchronizing and minimizing the variation of all the parts of an industrial process so that mass production was possible".

$\mathrm{P}$

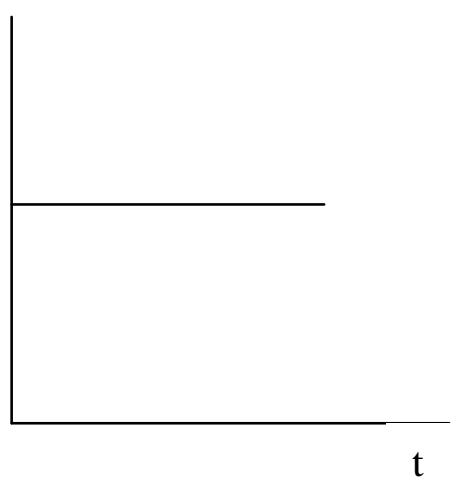

$\mathrm{P}=$ performance, $\mathrm{t}=$ time

Figure 4: control paradigm

International conference on Quality in Education and Training 2017, Innovative Universities for Smart Cities, Kenitra, 12-13 May 
Shiba recognizes in this paradigm the Theory-X- vision of McGregor (McGregor, 1985): "people want stability and to be managed". The middle manager plays the central role in quality. We might change the processes, but keep the standards unchanged.

Hardjono sees a focus on effectiveness and efficiency (Hardjono, 1995). The definition of quality in this paradigm is: the extent to which the object fits to the standards. In the educational setting this could mean: does education provide society with graduates that have the knowledge and skills society needs.

\section{Continuous improvement}

In the second value system the World is a universe full of chances to improve your own position as long as you put effort in it. Possibilities are unlimited. Results and profit are dominant. Beck and Cowan gave it the colour orange and called it "success' or StriveDrive. In quality management we prefer the title "continuous improvement".

Jouslin de Noray calls this the second revolution in quality management (Jouslin de Noray, 2004). It is about results and success. In this paradigm the customer has an important role to judge the success you have reached. Deming even speaks of 'delighting the customer". Here the Plan-Do-Check-Act cycle is crucial. Models used are the Malcolm Baldrige Award, The Excellence model (EFQM), methods like the Balanced Scorecard and Six Sigma .Shiba (Shiba, 2005) calls it "incremental improvement". "Incremental improvement is symbolically indicated by the staircase graph, indicative of the goal of incrementally and repeatedly improving the business' product or service offers and the processes of providing".

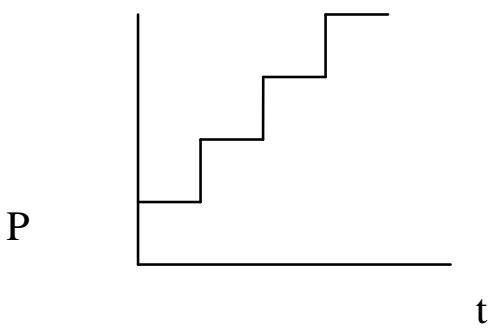

$\mathrm{P}=$ performance, $\mathrm{t}=$ time

Figure 5: continuous improvement paradigm

He recognizes in this paradigm the Theory-Y- vision of McGregor (McGregor, 1985): "people want self determination and improvement". The shop floor worker plays the central role in quality. We might change the standards, but keep the business unchanged.

The definition of quality in this paradigm is: the extent to which the object exceeds the expectations of the customer. In an education stetting this could mean: do we exceed the learning results that are asked for by students and the world of work?

\section{Commitment}

In the third value system the World is a a place where people live that are equal. Contact is cherished. People become members of a community, seek for harmony. Dominant are the human factor and connection. Beck and Cowan gave it the colour green and called it "community" or HumanBond. Like Vinkenburg (2006) we prefer the title "commitment". Vinkenburg (Vinkenburg, 2006) sees the following characteristics of the commitment paradigm as opposed to the control paradigm. 


\begin{tabular}{|l|l|}
\hline Control & Commitment \\
\hline Explain, laws, cause-effect & Understand, intention, empathy \\
\hline Try to manipulate and rule the outside world & Try to understand, except the inside world \\
\hline We want to shape the world & We want to make the world worth living in \\
\hline Science, cool, ratio, calculable phenomena & Art, warm, feeling, incalculable phenomena \\
\hline Rational convincing & Rhetorical secuiding \\
\hline To measure is to know & Who measures, still knows nothing \\
\hline $\begin{array}{l}\text { Criteria like profitability, effectiveness, } \\
\text { alertness }\end{array}$ & Criteria like curiosity, wisdom, concern \\
\hline $\begin{array}{l}\text { "Herrschen als Grundmotiv der } \\
\text { Weltanschaung" } \\
\text { To rule as basic motive of the worldview }\end{array}$ & $\begin{array}{l}\text { "Lieben als Grundmotiv der } \\
\text { Weltanschaung" } \\
\text { To love as basic motive of the World view }\end{array}$ \\
\hline
\end{tabular}

Table 1: control versus commitment

Shiba and Walden (2006) do not mention this paradigm, although they dedicate a chapter of their book to communities and societal values. They see an increasing need for shared learning and integration with a variety of extra business societal concerns. The move from continuous improvement to breakthrough can have arrogance as a barrier. The arrogance here is, that the producer thinks, that "what is already being made and sold is what customers will always want". Also in education competences needed change,,,, To break this barrier involves relooking at the fundamental objectives of the business and seeking new societal values beyond current business interests. For that, Shiba and Walden state, communities are needed. Organisations in this paradigm have socialisation competence in the words of Hardjono (1995). They are oriented towards flexibility. The organisation is focused not only on the success here and now, but also in the rest of the world and for future generations. Quality is the extent to which the goals of all stakeholders are fulfilled, taking into account here and now, and the future. In an educational setting this could mean: do the students get transformed into citizens of the world?

\section{Breakthrough}

In the value system of Synergy the World is complex and full of choices and dilemmas. Everything changes fast. People create space to think and analyse. Systems thinking and intellectual freedom are dominant values. Beck and Cowan gave this value system the colour of yellow and named it : "synergy" or FlexFlow. In quality management we prefer the title breakthrough. Jouslin de Noray calls breakthrough the third revolution in quality management (Jouslin de Noray, 2004). It is about innovation. Shiba and Walden define breakthrough as "a fundamental change in an organization's direction - as response to an abrupt, radical change in the business environment" (Shiba and Walden, 2006). Shiba (2005) argues, that in the seventies and eighties incremental improvement was not enough for companies to survive. They had to look for new businesses. Change the business, let the values be unchanged. Central role in this breakthrough play the "top-upper managers. "In the quest for breakthrough we must move beyond rational thinking in some circumstances". Shiba calls it besides Mc Gregors Theory X en Y: Theory Z. Characteristic is the visual representation he gives. A business has its own life cycle, before the decrease a company should re-invent itself, redesign its processes and start a new life cycle. 


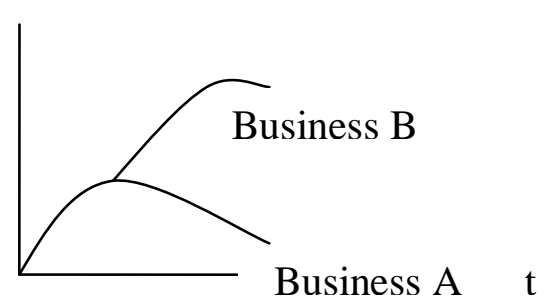

$\mathrm{P}=$ performance, $\mathrm{t}=$ time

Figure 6: breakthrough paradigm from business A to business B.

Organisations in this paradigm have according to Hardjono (1995) intellectual competence.

They are oriented at creativity. Quality is the extent to which the goals of all stakeholders will be fulfilled in the future. In the educational setting this could mean: are students grown up to be leaders in the future society? 


\begin{tabular}{|c|c|c|c|c|}
\hline Value system & Control & $\begin{array}{l}\begin{array}{l}\text { Continuous } \\
\text { improvement }\end{array} \\
\end{array}$ & Commitment & Breakthrough \\
\hline Beck and Cowan & $\begin{array}{l}\text { ORDER } \\
\text { TruthForce } \\
\text { "Everything has a purpose, a place and a } \\
\text { reason". }\end{array}$ & $\begin{array}{l}\text { SUCCESS } \\
\text { StriveDrive } \\
\text { "People are meant to } \\
\text { succeed and become } \\
\text { winners". }\end{array}$ & $\begin{array}{l}\text { COMMUNITY } \\
\text { HumanBond } \\
\text { "There is plenty of room for everyone". }\end{array}$ & $\begin{array}{l}\text { SYNERGY } \\
\text { FlexFlow } \\
\text { "We are open to learning at any time } \\
\text { and from any source". }\end{array}$ \\
\hline Characteristics & $\begin{array}{l}\text { Only one right way } \\
\text { Purpose in causes } \\
\text { Guilt in consequences } \\
\text { Sacrifice for honour }\end{array}$ & $\begin{array}{l}\text { Competes for success } \\
\text { Goal-oriented drives } \\
\text { Change to progress } \\
\text { Material gain/perks }\end{array}$ & $\begin{array}{l}\text { Seeks inner peace } \\
\text { Everybody is equal } \\
\text { Everything is relative } \\
\text { Harmony in the group }\end{array}$ & $\begin{array}{l}\text { Big picture views } \\
\text { Integrative structures } \\
\text { Naturalness of chaos } \\
\text { Inevitability of change }\end{array}$ \\
\hline $\begin{array}{l}\text { University life } \\
\text { (Pupius, 2007) }\end{array}$ & $\begin{array}{l}\text { Rules and regulations } \\
\text { Hierarchical structures } \\
\text { Budgeting } \\
\text { Quality assurance by means of quality } \\
\text { control }\end{array}$ & $\begin{array}{l}\text { Goal orientation, } \\
\text { enterprise initiatives, } \\
\text { managing as a business. } \\
\text { Business planning. } \\
\text { Excellence Model } \\
\text { Balanced Scorecard }\end{array}$ & $\begin{array}{l}\text { Consensus management, } \\
\text { political correctness, environmental concerns, } \\
\text { People concerns } \\
\text { People development }\end{array}$ & $\begin{array}{l}\text { Systems and processes } \\
\text { Reduction in hierarchical command and } \\
\text { control. } \\
\text { Cross-university collaboration } \\
\text { Self-managed teams }\end{array}$ \\
\hline Quality = & $\begin{array}{l}\text { The extent to which an object fits to } \\
\text { standards. }\end{array}$ & $\begin{array}{l}\text { The extent to which } \\
\text { the expectations of the } \\
\text { customer are } \\
\text { exceeded. }\end{array}$ & $\begin{array}{l}\text { The extent to which the goals of all stakeholders are } \\
\text { fulfilled, taking into account here and now, there and } \\
\text { the future. }\end{array}$ & $\begin{array}{l}\text { The extent to which the goals of all } \\
\text { stakeholders will be fulfilled in the } \\
\text { future. }\end{array}$ \\
\hline Object & Product, profession, process, system & Organisation & & \\
\hline Basic rules & $\begin{array}{l}\text { Standards; } \\
\text { ISO9000:1994 }\end{array}$ & $\begin{array}{l}\text { Phases of development; } \\
\text { ISO 9001:2000; } \\
\text { Management contracts }\end{array}$ & Social and psychological contracts, interaction, consensus & $\begin{array}{l}\text { Dialogue, "simple rules" (Stacey et al., } \\
\text { 2000) }\end{array}$ \\
\hline Subject & Third party audits & The customers & All stakeholders & \\
\hline In Higher Education & Accreditation systems & EFQM, Malcolm Baldrige & AISHE & ???? \\
\hline Names & Taylor, Shewhart & $\begin{array}{l}\text { Deming, Feigenbaum, } \\
\text { Imai, Crosby }\end{array}$ & (Vinkenburg, 2006) & $\begin{array}{l}\text { (Shiba, 2006), (Jouslin de Noray, 2004), } \\
\text { (Stacey et al., 2000) }\end{array}$ \\
\hline $\begin{array}{l}\text { Jouslin de Noray } \\
\text { (2004) } \\
\text { revolutions in QM }\end{array}$ & Process control & $\begin{array}{l}\text { Integral Quality } \\
\text { Management }\end{array}$ & Breakthrough & \\
\hline $\begin{array}{l}\text { Shiba }(2005,2006) \\
\text { Change } \\
\text { Unchange } \\
\text { Human being } \\
\text { Key player }\end{array}$ & $\begin{array}{l}\text { Process } \\
\text { Standards } \\
\text { Theory } X \\
\text { Middle manager }\end{array}$ & $\begin{array}{l}\text { Standards } \\
\text { Business } \\
\text { Theory Y } \\
\text { Shop floor workers }\end{array}$ & $\begin{array}{l}\text { Business } \\
\text { Values } \\
\text { Theory z } \\
\text { Top-upper managers }\end{array}$ & \\
\hline Vinkenburg (2006) & Control paradigm & & Commitment paradigm & \\
\hline Hardjono (1995) & $\begin{array}{l}\text { Orientation on effectiveness and } \\
\text { efficiency } \\
\text { Material and commercial competence }\end{array}$ & $\begin{array}{l}\text { Orientation on flexibility } \\
\text { Socialization competence }\end{array}$ & & $\begin{array}{l}\text { Orientation on creativity } \\
\text { Intellectual competence }\end{array}$ \\
\hline
\end{tabular}

Table 2: Value System Definition

International conference on Quality in Education and Training 2017, Innovative Universities for Smart Cities, Kenitra, 12-13 May 


\section{Developments in Higher Education.}

What is the use of these paradigms for Higher Education in times of Smart Cities? Most universities, I presume, recognize themselves in the paradigms of control or continuous improvement (or parts of both). For a breakthrough, that is needed in times of smart cities more than that is required. We need a university that is pluralistic, based on commitment. A university that focuses on a quality culture and empowerment to achieve extraordinary employee motivation. That requires participative leadership.

\section{(Pluralistic) GREEN organizations}

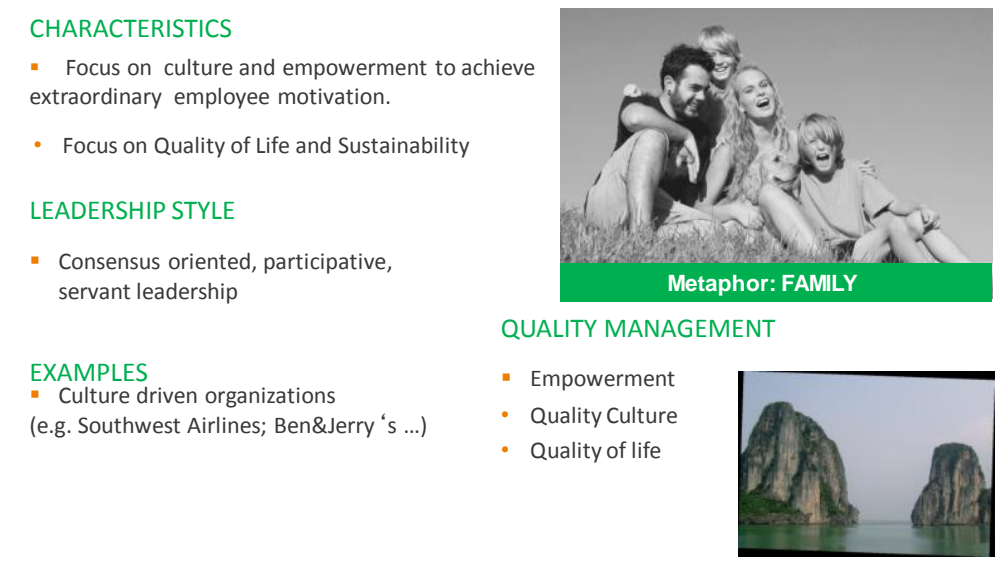

Figure 7: Characteristics of the commitment paradigm

Kemenade (2017) developed the EMERGENGY MODEL (c) to score a university in its development, in five stages. A part of the scorecard is presented as figure 8 .

\section{Conclusion}

The paradigms as presented in this article give way to the explanation of actual developments in internal and external quality management. They might even show the way for the future. "The strategic choice of an organisation should based on an equilibrium between outside and inside orientation on the one hand and between an orientation based on control and change on the other" (Hardjono, 1995). Breakthrough towards a Smart University will only be possible if the organisation has enough control, and enough stability as a solid base to build on. You need control, continuous improvement and community to get to breakthrough. In the words of Beck and Cowan (1996): 'They come like waves to the beach. Each has its own ascending surge, designed to fathom the Life Conditions of its world. At the same time, each also overlaps the receding waves of the previous systems as they fade'. The stage the university is in and how to get there can be measured. 


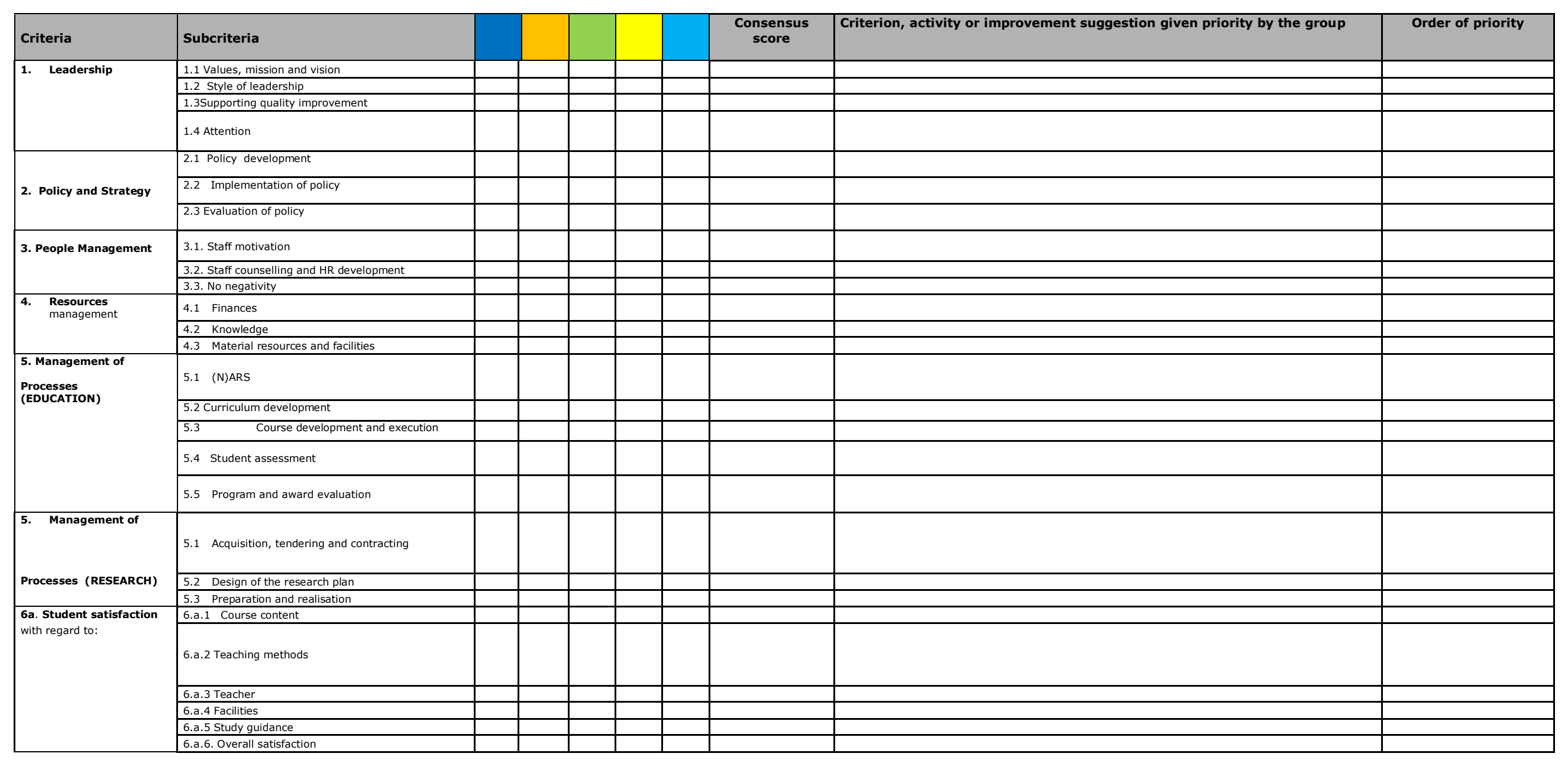

Figure 8: Scorecard EMERGENCY MODEL (c) (part 1) 


\section{References}

BECK R. And COWAN, C. (1996) Spiral Dynamics, Malden, Blackwell Publishers.

DEAKIN, M.; Al WAER, H.(2011) "From Intelligent to Smart Cities". Journal of Intelligent

Buildings International: From Intelligent Cities to Smart Cities. 3 (3)

doi: 10.1080/17508975.2011.586671.

GIFFINGER, R., FERTNER, C., KRAMAR,H.,KALASEK,R., PICHLER-MILANOVIC, N.

\& MEIJERS,E. (2007) Smart Cities - Ranking of European medium-sized cities, Vienna

University of Technology.

HARDJONO, T. W. (1995) Ritmiek en organisatiedynamiek, Deventer, Kluwer.

HARDJONO, T. W. (2005) Developments in Quality Management. ECOP meeting. Rotterdam.

JOUSLIN DE NORAY, B. (2004) Theory and Techniques on Breakthrough Change. EOQ 48th. Moscow, EOQ.

KUHN, T. S. (1970) The Structure of Scientific Revolutions, Chicago, University of Chicago Press.

LALOUX, F. (2014) „Reinventing organizations“, Lannoo Campus

MCGREGOR, D. (1985) The Human Side of Enterprise, New York, McGraw-Hill.

SHIBA, S. (2005) Explore University education. Quality and Accreditation in European Higher Education:

friends or enemies? Antalya, EOQ.

SHIBA, S. (2006) Transformation Case Studies, Salem, Goa/QPC.

SHIBA, S. \& WALDEN, D. (2006) Breakthrough Management, New Delhi, Confederation of Indian Industry.

Slavova,M. and Okwechime, E. (2016). "African smart cities strategies for Agenda 2063"

Africa Journal of Management, 2: 210-229.

STACEY, R. D., GRIFFIN, D. \& SHAW, P. (2000) Complexity and management, London and New York,

Routledge.

VAN KEMENADE, E. E. (2004) Methode voor kwaliteitsverbetering van het Hoger Onderwijs op basis van het EFQM-model, Groningen/Eindhoven, Expertgroep HBO.

VAN KEMENADE, E.A., PUPIUS, M. \& HARDJONO, T.W. (2008), More value to defining quality, Quality in Higher Education, 14, 2, pp. 175-185

VAN KEMENADE, E.A (2010), Past is prologue. Know the history of quality management to achieve future success, Quality Progress, August 2010.

VAN KEMENADE, E.A., (2014) Theory C. The near future of Quality management, The TQM Journal, Vol. 26 No. 6, pp. 650-657

VAN KEMENADE, E.A. (2015), Contextual Divide, Quality Progress, American Society for Quality,

November 2015

VAN KEMENADE, E.A. (2017), The Myth of the PDCA-cycle in Times of Emergent Change, Eurashe seminar on quality assurance "Managing your institution's quality with the latest practices and policies, Brussels, 6-7 February 2017

VAN KEMENADE, E.A. (2017) The Emergency Model (c) private press

VINKENBURG, H. H. M. (2006) Dienstverlening; paradigma's, deugden en dilemma's, Deventer, Kluwer. 